BIOMEDICINE

\title{
Expression of different subunits of eukaryotic translation elongation factor eEF1 in human glial brain tumors.
}

\author{
M. V. Veremieva, K. O. Shostak, T. A. Malysheva ${ }^{1}$, Y. P. Zozulya ${ }^{1}$, V. D. Rozumenko ${ }^{1}$, \\ V. M. Kavsan, B.S. Negrutskii.
}

Institute of Molecular Biology and Genetics of National Academy of Sciences of Ukraine 150, Zabolotny Str., Kyiv, 03680, Ukraine

${ }^{1}$ A.P. Romodanov Institute of Neurosurgery of AMS of Ukraine

32 Manuilskoho Str., Kyiv, 04050,Ukraine

vermarina@list.ru

\begin{abstract}
Eukaryotic elongation factor 1 (eEFl) mediates the binding of aminoacyl-tRNA to the ribosome in

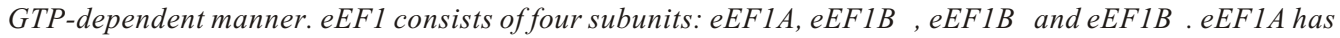
two different isoforms: eEF1A1 is present throughout development and is ubiquitously expressed with the exception of adult muscle, while eEF1A2 is developmentally regulated and expressed only in muscle cells

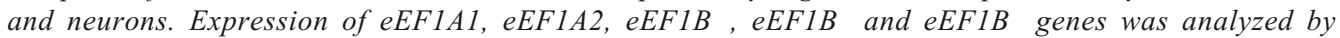
Northern blot hybridization of a panel of brain tumor and normal brain tissue RNAs. Totally 23 glioblastoma and 10 normal brain samples were investigated. In gliomas, no meaningful difference in the

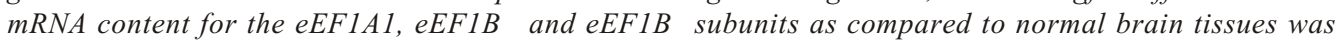
found. However, we have observed approximately 2-fold decrease in the eEF1B $\beta$ mRNA expression in human gliomas as compared to normal human brain by Northern blot analysis. Besides, we have shown reduced level of the eEF1A2 $\mathrm{mRNA}$ expression in glioblastoma as compared to normal human glia.
\end{abstract}

Keywords: eEF1, eukaryotic translation elongation factor 1, overexpression of genes, human glial brain tumors.

Introduction. Elongation factor 1 (eEF1) is a multiprotein complex playing a pivotal role in the translation of genetic information in eukaryotic cell. The complex consists of four functionally different subunits: eEF1A is responsible for the delivery of correct aminoacyl-tRNA to the A- site of

(C) M. V. VEREMIEVA, K. O. SHOSTAK, T. A. MALYSHEVA, Y. P. ZOZULYA, V. D. ROZUMENKO, V. M. KAVSAN, B.S. NEGRUTSKII, 2008
mRNA-programmed 80S ribosome and supposedly facilitates the transport of deacylated tRNA back to the aminoacyl-tRNA synthetase for recharging [1]. The structurally different subunits eEF1B $\alpha$ and eEF1B $\beta$ catalyze the exchange of GDP for GTP in the eEF1A molecule, and the eEF1B $\gamma$ subunit is believed to serve as a "glue" to keep all subunits of the eEF1B complex together [2, 3, 4]. 


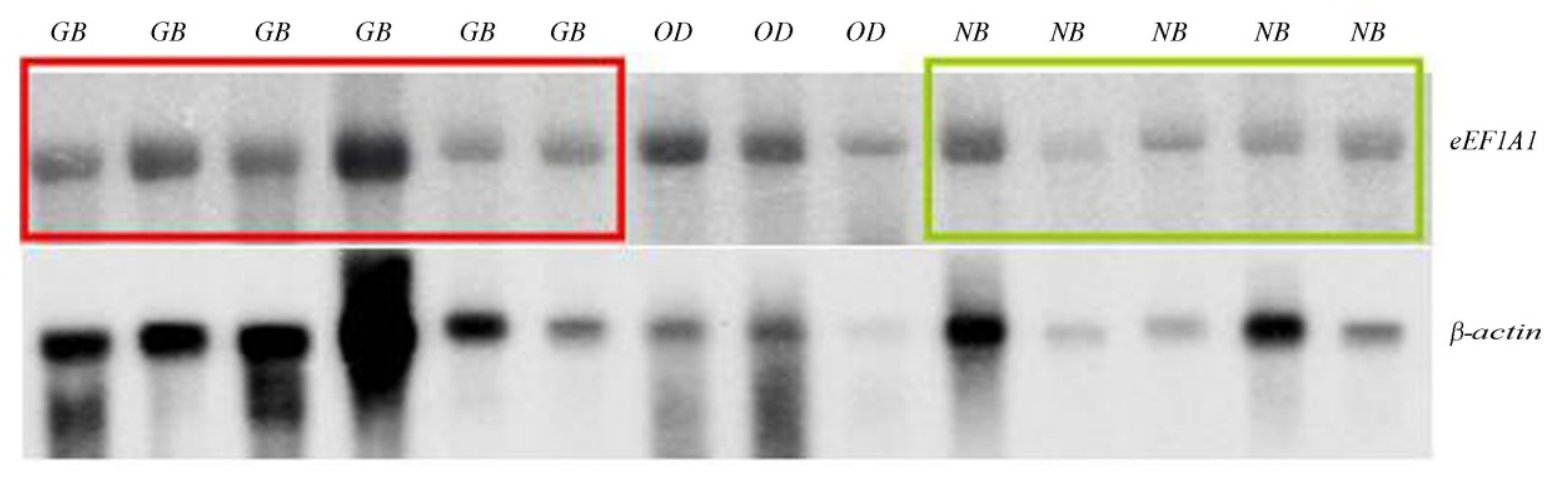

$a$

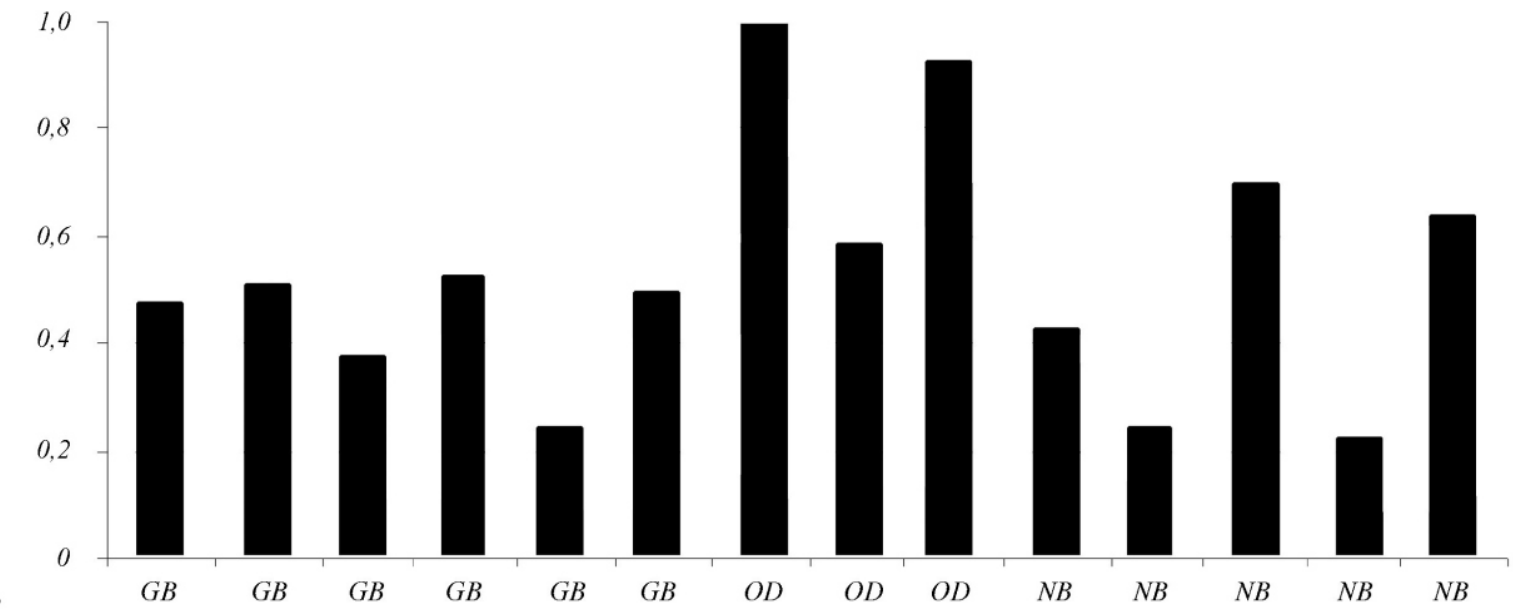

Fig.1. Northern blot hybridization of $\left[{ }^{32} \mathrm{P}\right]$ marked probe of eEF1A1 cDNA and $\beta$-actin cDNA with RNA samples of human brain tissue (a: NB - normal human brain; GB - glioblastoma; OD - oligodendroglioma), b - densitometric analysis.

It is becoming increasingly evident that the constituents of mammalian translation machinery play an important role in carcinogenesis. A recent research has shown clearly a potential oncogenic role of the translation elongation factors. Thus, eEF1A besides its well known housekeeping role might participate in the malignant transformation of cells. The transformation ability of eEF1A1 was assumed long time ago [5], but recently the important role in carcinogenesis has been ascribed to another isoform of eEF1A - eEF1A2. The expression of the eEF1A isoforms is mutually exclusive: eEF1A2 is found in brain and muscles while eEF1A1 is present in all other tissues of the organism. The appearance of the eEF1A2 isoform in non-inherent tissues such as ovary or mammary gland is directly linked to carcinogenesis $[6,7]$. Since the eEF1A2 isoform is normally expressed in neuronal rather than glial brain tissue it is tempting to investigate if glial types of cancer could be coupled with the admission of eEF1A2.

Overexpression of the eEF1B $\beta$ and eEF1B $\gamma$ subunits was also found in certain types of human cancer [8 - 12]. However, no information about expression of the eEF1B complex in brain cancer is available until now.

The aim of present work is to investigate the expression level of mRNAs coding all subunits of the eEF1 complex including the eEF1A2 isoform in human glioblastomas and normal brain.

Materials and methods. The samples of astrocytic gliomas, World Health Organization (WHO) II - IV grade, were obtained from the A.P. Romodanov Institute of Neurosurgery (Ukraine). The tumors were classified on the basis of examination of hematoxilin and eosin stained sections of the surgical specimens according to the WHO criteria. The surgical specimen of histologically normal brain tissue adjacent to the 
tumor serves as a source of normal adult human brain RNA.

The samples of embryonic tissues were obtained from the Center of Embryonic Tissues "EM CELL" (Ukraine).

Plasmids with eEF1A1, eEF1A2, eEF1B $\alpha$, eEF1B $\beta$ and eEF1B $\gamma$ cDNAs inserts were received from V. Shalak, Institute of molecular biology and genetics NASU, Ukraine, C. Knudsen, Aarhus University, Denmark and G. Sheu, Chung Shan Medical University, Taichung, Taiwan.

Total RNA was isolated from frozen tissues according to Chomczynski and Sacchi [13]. RNA (0.01 $\mathrm{mg}$ per lane) was electrophoretically separated in a $1.5 \%$ agarose gel containing $2.2 \mathrm{M}$ formaldehyde and then transferred to a Hybond-N nylon membrane (GE Healthcare Bio-Sciences Corp., USA).

$\left[{ }^{32} \mathrm{P}\right]$-labeled probe was produced with RediPrime II kit (GE Healthcare Bio-Sciences Corp.) using fragments of the eEF1A1, eEF1A2, eEF1B $\alpha, \mathrm{eEF} 1 \mathrm{~B} \beta$ and $\mathrm{eEF} 1 \mathrm{~B} \gamma \mathrm{cDNAs}$ obtained after digestion of the plasmid by corresponding endonucleases [14].

RNA-containing membrane was incubated with $\left[{ }^{32} \mathrm{P}\right]$-labeled cDNA probes in $50 \%$ formamide, $5 \mathrm{x}$ SSC, $5 \times$ Denhardt's solution, $0.5 \%$ SDS and 0.01 $\mathrm{mg} / \mathrm{ml}$ salmon sperm DNA at $42{ }^{\circ} \mathrm{C}$ overnight.

Extensive washing was performed twice with $2 \mathrm{x}$ $\mathrm{SSC}, 0.1 \% \mathrm{SDS}$ for $15 \mathrm{~min}$ at room temperature; once with $2 \times \mathrm{SSC}, 0.1 \% \mathrm{SDS}$ for $30 \mathrm{~min}$ at $65^{\circ} \mathrm{C}$; and finally with $0.2 \times \mathrm{SSC}, 0.1 \% \mathrm{SDS}$ for $30 \mathrm{~min}$ at $65{ }^{\circ} \mathrm{C}$. Subsequently, the membrane was exposed to a radiographic film with an intensifying screen at $-70{ }^{\circ} \mathrm{C}$. The membrane was re-hybridized with the $\left[{ }^{32} \mathrm{P}\right]$-labeled human $\beta$-actin cDNA probe used as a control of RNA gel loading.

RT-PCR was performed using $1-5 \mathrm{mg}$ of total RNA and RevertAid M-MuLV Reverse Transcriptase ("Fermentas", Lithuania) according to the manufacture's protocol under the following conditions: $94{ }^{\circ} \mathrm{C} 3 \mathrm{~min}$, followed by 25 cycles each of $94^{\circ} \mathrm{C} 30 \mathrm{sec}$, $58^{\circ} \mathrm{C} 60 \mathrm{sec}$ and $72^{\circ} \mathrm{C} 60 \mathrm{sec}$ and after the last one $72^{\circ} \mathrm{C}$ $7 \mathrm{~min}$. PCR products were analyzed by separating in $1 \%$ agarose gel.

Primer sequences were as follows:

eEF1A1 -

f 5'GCATCCTACCACCAACTCGT 3', r 5'CAGCATCACCAGACTTCAA 3';

eEF1A2 -

f 5'GAGAAGCGCTACGACGAGAT 3', r 5'CTTCACCGACACGTTCTTCA 3'; eEF1B $\beta$ -

f 5' GCGTCAGAAAAATGGCTAC 3', r 5' TCCTCCTCATTGTCACTGCCAAAC 3'.

Densitometric analysis of the hybridization signals was performed by the Scion Image program.

Results and discussion.Expression of the eEF1A1, eEF1A2, eEF1B $\alpha$, eEF1B $\beta$ and eEF1B $\gamma$ genes was analyzed by Northern blot hybridization of a panel of brain tumor and normal brain tissue RNAs. Totally 23 glioblastoma and 10 normal brain samples were investigated.

The mRNA, coding for glial tissue eEF1A1 isoform, is found to be highly expressed, and no difference in the eEF1A1 mRNA level was found between normal brain and glioblastoma samples (Fig.1).

Normally the eEF1A2 isoform is expressed in neurons rather than in glial tissue. Since the samples of normal brain represented mix of glia and neurons, a positive signal of eEF1A2 expression was possible to be detected in these samples. It is thought that the appearance of eEF1A2 in non-specific for this isoform tissue is related to the carcinogenesis $[6,7]$. Therefore, it is of substantial interest to research if the expression of eEF1A2 commences during glial cancer, namely in astrocytic gliomas of different grades. In control experiments the eEF1A2 cDNA was hybridized with total RNA isolated from the rabbit muscles, brain and liver. A high level of expression was observed in the muscle sample, less intense signal was detected with RNA from the brain tissue and no signal in the liver sample (Fig. 2 a). Importantly, a low occurrence of the eEF1A2 mRNA was observed in the gliomas samples (Fig.2 b).

Thus, the isoforms of eEF1A, which were directly shown oncogenic in several cell lines and tissues, do not reveal elevated level of mRNA in glioma brain tumors.

The genes coding for eEF1B $\beta$ and eEF1B $\gamma$ subunits of eEF1B complex were shown to be overexpressed in different types of cancer [8 - 12]. No information about their mRNAs level in the brain tumors is now 


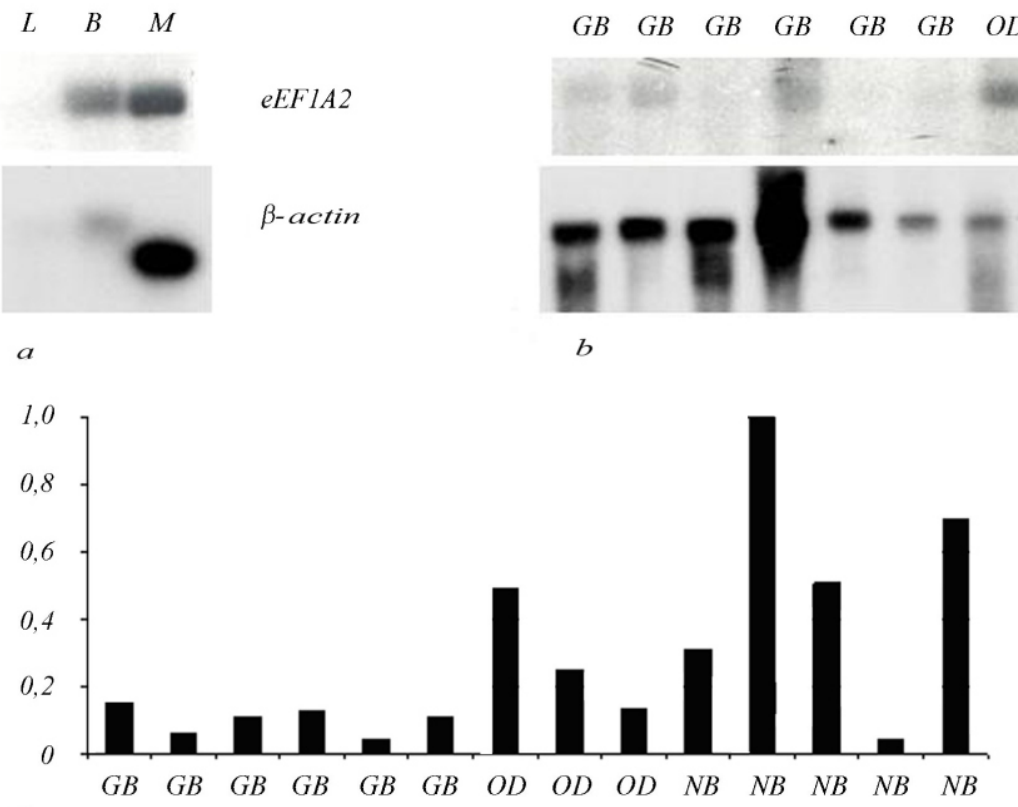

Fig.2. Northern blot hybridization of $\left[{ }^{32} \mathrm{P}\right]$ marked probe of eEF1A2 cDNA and $\beta$-actin cDNA with RNA samples of different rabbit tissues (a: $\mathrm{L}$ - liver, $\mathrm{B}$ - brain, $\mathrm{M}$ - muscles) and human brain tissue (b: NB - normal human brain tissue, GB glioblastoma, OD - oligodendroglioma), c densitometric analysis.

c

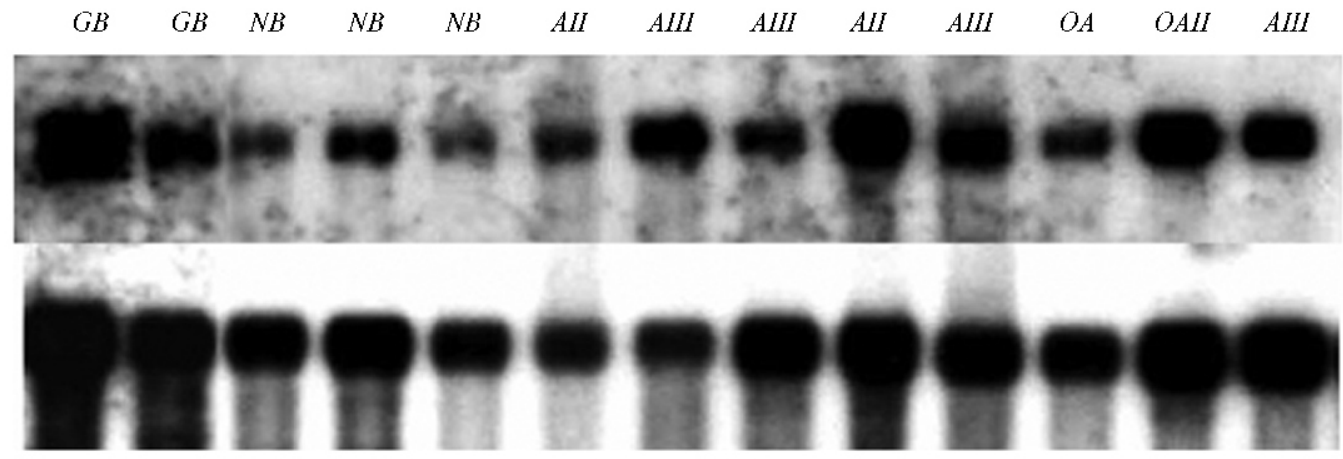

$e E F / B \alpha$

$a$

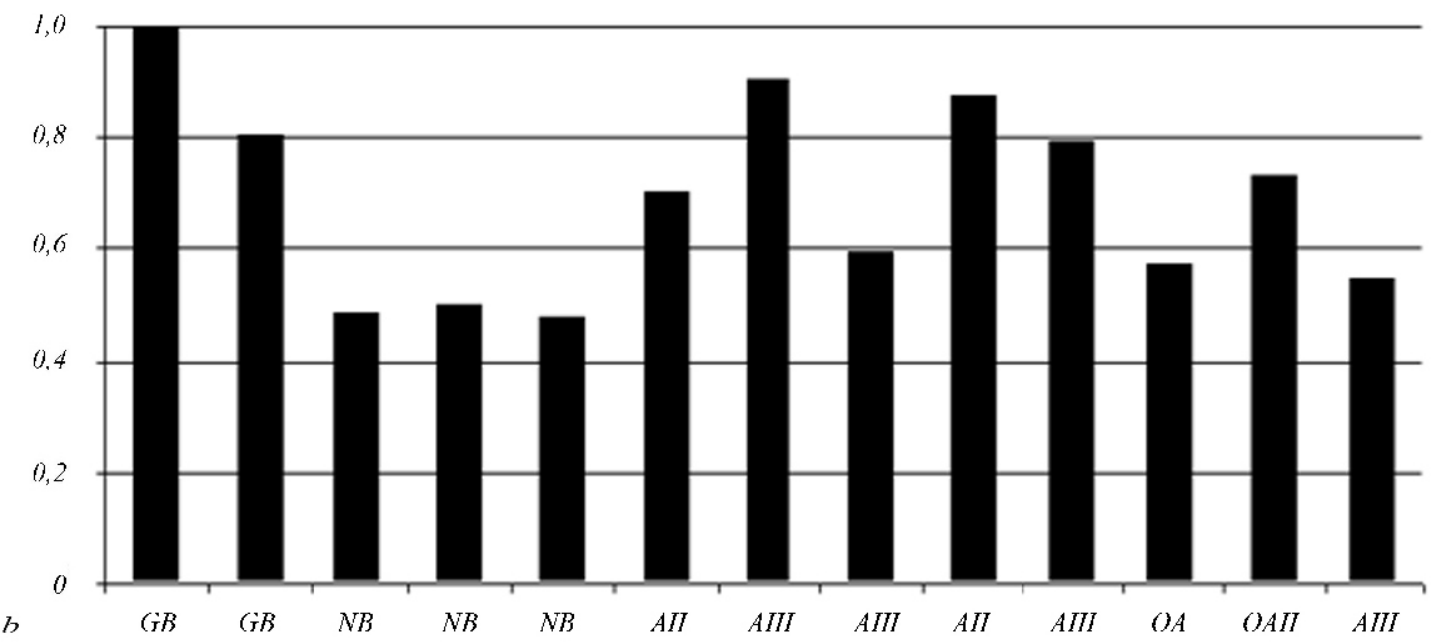

Fig.3. Northern blot hybridization of $\left[{ }^{32} \mathrm{P}\right]$ marked probe of eEF1B6 cDNA and $\beta$-actin cDNA with RNA samples of human brain tissue (a: NB - normal human brain, GB - glioblastoma, AII - astrocytoma II grade, AIII - astrocytoma III grade, OA - oligodendroastrocytoma, OAII - oligodendroastrocytoma II grade); b - densitometric analysis. 

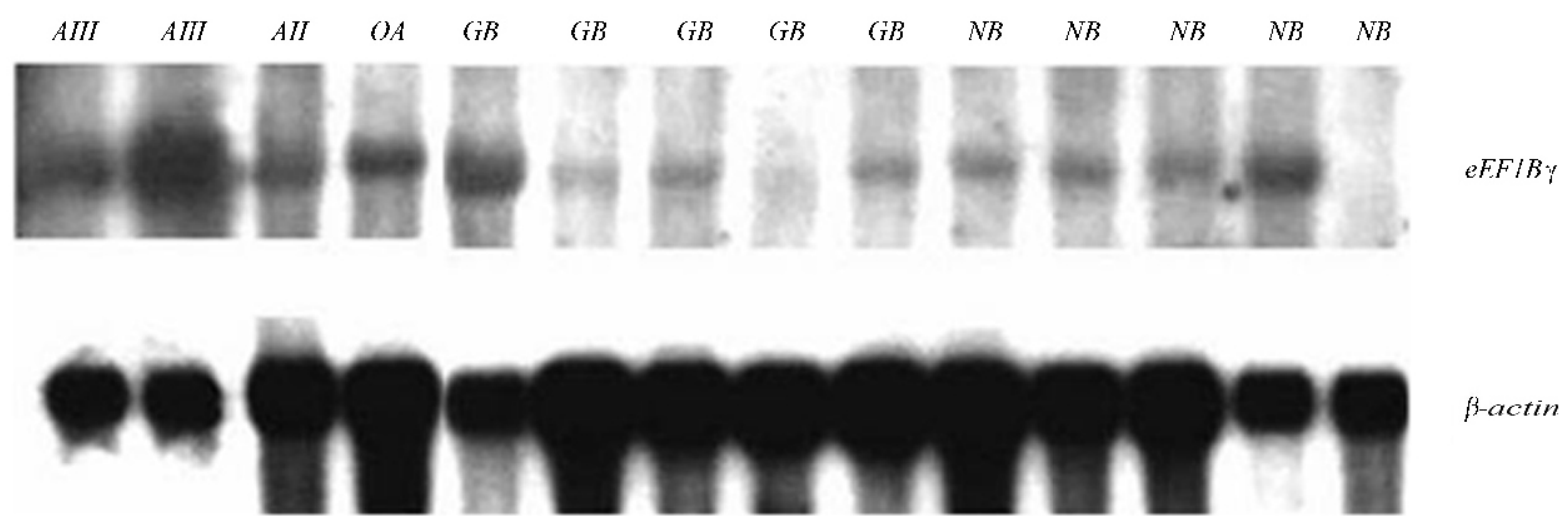

CI

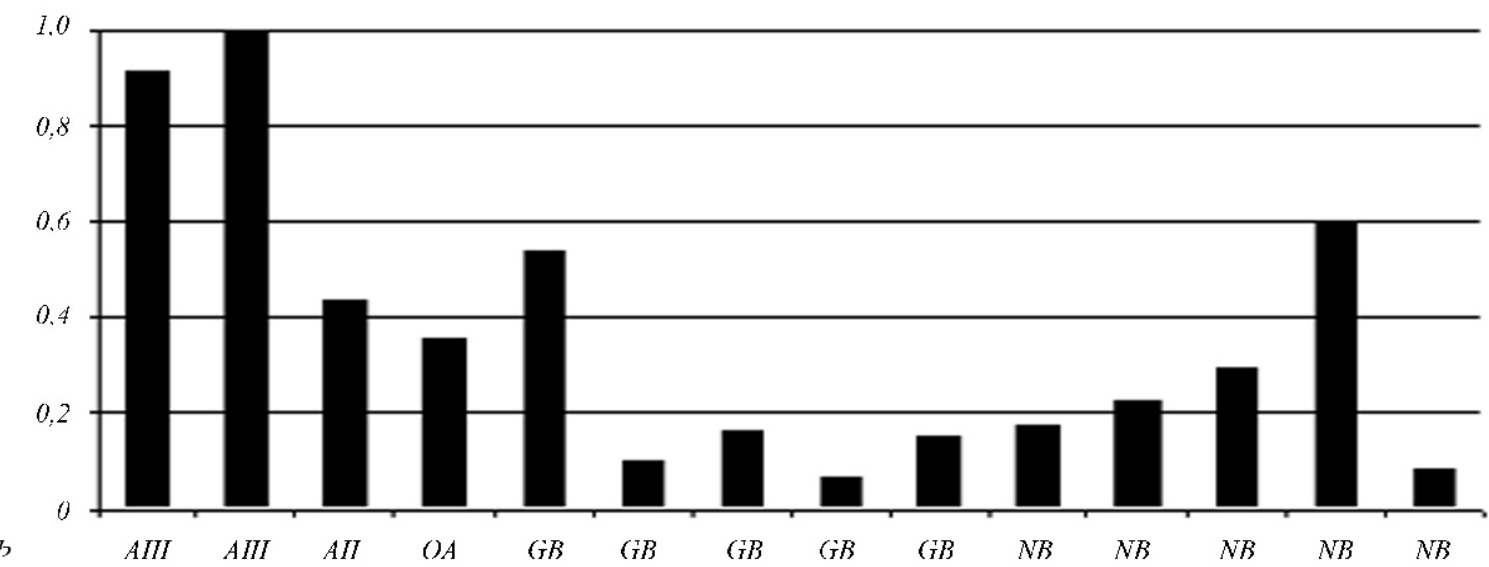

Fig.4. Northern blot hybridization of $\left[{ }^{32} \mathrm{P}\right]$ marked probe of eEF1Bг cDNA and $\beta$-actin cDNA with RNA samples of human brain tissue (a: NB - normal human brain, GB - glioblastoma, AII - astrocytoma II grade, AIII - astrocytoma III grade, OA - oligodendroastrocytoma); b densitometric analysis.

available. Interestingly, despite the subunit stoichiometry in the eEF1B complex being 1:1:1 the expression level of different subunits during carcinogenesis is not always coordinated [8 - 12]. In other words, overexpression of the eEF1B $\gamma$ subunit is not necessarily accompanied by overexpression of the eEF1B $\beta$ subunit and vise verse. It suggests a novel, non-translational, cancer-related function of the subunits. Therefore, it is important to analyze the level of expression of the eEF1B complex subunits in the normal and cancerous brain.

No differences in the expression level of eEF1B $\alpha$ (Fig. 3) and eEF1B $\gamma$ (Fig. 4) genes in the brain tumor comparing to the normal brain samples were found by Northern blot hybridization of corresponding cDNAs with panel of RNAs derived from the brain tissue. If the equally high expression of eEF1B $\alpha$ in normal and cancer tissues was not surprising (the elevated expression of this subunit was never observed during carcinogenesis), the absence of the eEF1B $\gamma$ overexpression suggests its non-involvement in the brain cancer development, contrary to the tumors of different origin [8 - 10].

Unexpectedly, no eEF1B $\beta$ gene expression was detected in both normal brain and glioblastoma by the Northern blot technique (Fig. 5 a). For a positive test of the eEF1B $\beta$ expression we used human embryonic tissues where the eEF1B $\beta$ mRNA was observed (Fig.5 b). Consequently, more sensitive RT-PCR method was used to examine the eEF1B $\beta$ expression in the human brain. The PCR technique indeed revealed the eEF1B $\beta$ expression in normal brain and glioblastomas (Fig. 6). The level of eEF1B $\beta$ mRNA expression is rather low and could be beyond a detection limit of the Northern blot procedure. No difference between the eEF1B $\beta$ 

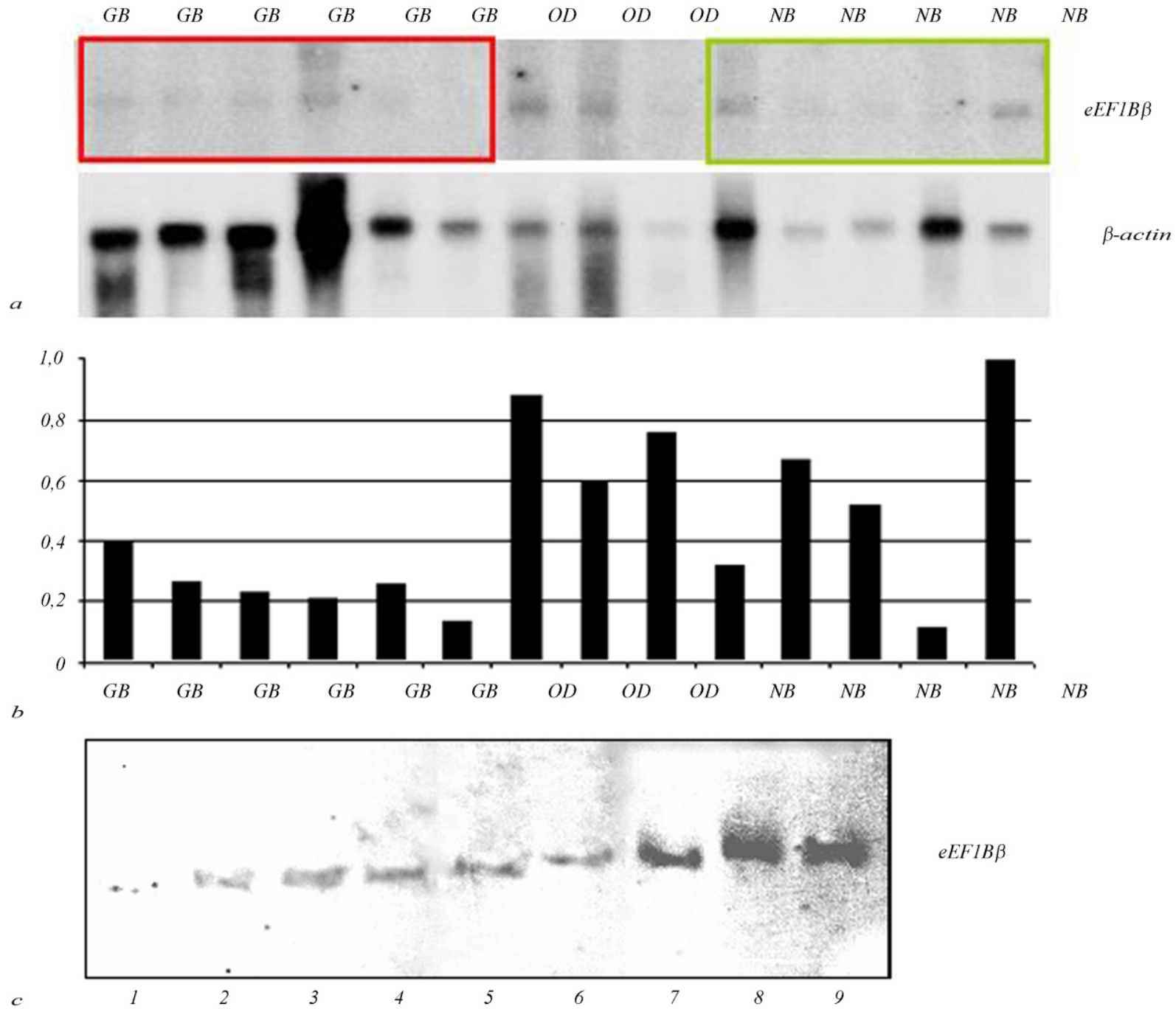

Fig.5. Northern blot hybridization of $\left[{ }^{32} \mathrm{P}\right]$ marked probe of eEF1B $\beta$ cDNA and $\beta$-actin cDNA with RNA samples of human brain tissue (a: NB - normal human brain; GB - glioblastoma; OD - oligodendroglioma) and human embryonic tissues (c: 1 - kidney, 6 weeks; 2 - kidney, 7 weeks; 3 - brain, 6 weeks; 4 - brain, 7 weeks; 5 -liver, 6 weeks; 6 -liver, 7 weeks; 7 -liver, 8 weeks; 8 -liver, 9 weeks; 9 - liver, 10 weeks), $\mathrm{b}-$ densitometric analysis.

mRNA level in normal brain and glioblastoma could be disclosed at present.

Low quantity of eEF1B $\beta$ mRNA in the brain is a surprising finding taking into account aforementioned $1: 1: 1$ stoichiometry of the eEF1B complex. It was suggested recently that M4 muscarinic receptor could take over the GDP/GTP exchange role for eEF1A in some tissues [16] thus explaining low presence of eEF1B $\beta$ in the brain samples.

It is necessary to note that the differences were observed in the eEF1B subunits expression level between individual tumors, with a few tumors samples exhibiting either high or low amounts of individual transcripts. Such differences in gene expression

undoubtedly contribute to the observed heterogeneity in the biological properties of cancers derived from the same organ.

Further investigation of the eEF1B subunits level by Western blotting will help to reveal more accurately the composition of the eEF1B complex in the human brain and a possible cancer-related role of eEF1B $\beta$ subunit.

This work was partially supported by INTAS, the Fund for Fundamental Research of MES, Ukraine, cooperation between NAS of Ukraine, France and 


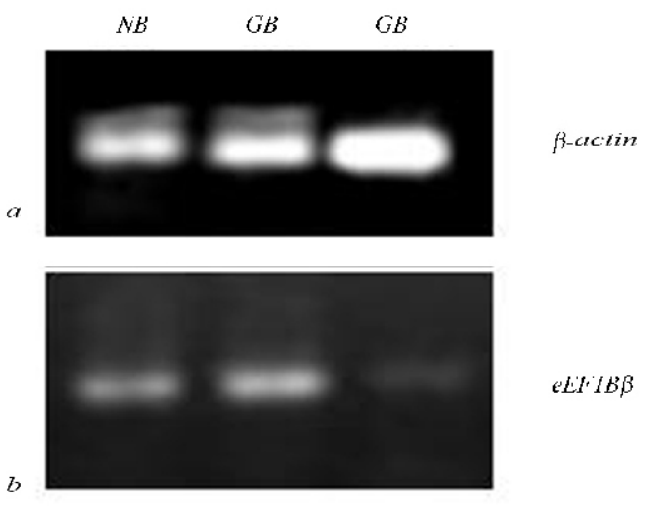

Fig.6. Gel-electrophoresis of PCR products with eEF1B $\beta$ (a) and $\beta$-actin (b) primers (NB - human normal brain; GB - glioblastoma) in $1 \%$ agarose gel.

\section{Russian Federation, Grant of the President of Ukraine for young scientists.}

М. В. Верем'єва, К. О. Шостак, Т. А. Малишева, Ю. П. Зозуля, В. Д. Розуменко, В. М. Кавсан, Б. С. Негруиький

Дослідження експресії різних субодиниць еукаріотного фактора елонгації трансляції еEF1 у гліальних пухлинах головного мозку людини

\section{Резюме}

Еукаріотний фактор елонгаиії трансляиії 1 (еEF1) є одним із основних компонентів транслячійного апарату клітини, який бере участь в елонгації білкового ланиюга. еЕF1 складається $з$

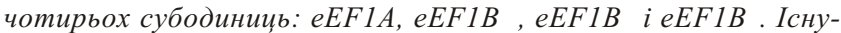
ють дві тканиноспецифічні ізоформи субодиниці еЕF1A-A1 $i$

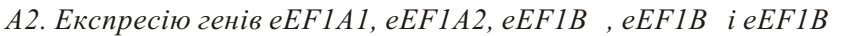
проаналізовано Нозерн-блот гібридизаџією панелі РНК пухлин і нормального головного мозку людини з відповідними олігонуклеотидними зондами. Загалом досліджено 23 зразки гліальних пухлин і 10 зразків нормального головного мозку людини. Нозерн-гібридизацією визначено відсутність відмінностей в

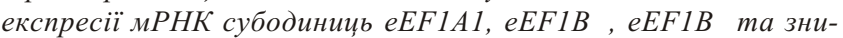
ження кількості мРНК еЕF1ВВ в гліобластомах порівняно 3 умовною нормою приблизно в два рази. Також показано зниження рівня експресії мРНК еЕF1A2 в зразках пухлин $у$ порівнянні з умовно нормальною глією людини.

Ключові слова: еЕF1, еукаріотний фактор елонгацї трансляиії 1, надекспресія гена, гліальні пухлини головного мозкулюдини.

М. В. Веремьева, К. О. Шостак, Т. А. Мальшева, Ю. П. Зозуля, В. Д. Розуменко, В. М. Кавсан, Б. С. Негруикий

Исследование экспрессии разных субъединиц эукариотного фактора элонгации трансляции еEF1 в глиальных опухолях головного мозга человека

Резюме
Эукариотный фактор элонгациии трансляциии 1 (еЕF1) является одним из основных компонентов трансляциионного аппарата клетки, участвующий в элонгации белковой иеепи. еЕF1 состо-

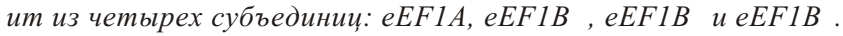
Существуют две тканеспеиифические изоформы субъединииь еEF1A (А1 и A2). Экспрессия генов еEF1A1, еEF1A2, еEF1B , еЕF1Bß и еЕF1B проанализирована Нозерн-блот гибридизаиией панели РНК опухолей и нормального головного мозга человека. Всего исследованы 23 образиа глиальных опухолей и 10 образиов нормального головного мозга человека. Нозерн-гибридизацией выявлено отсутствие отличий в экспрессии мРНК

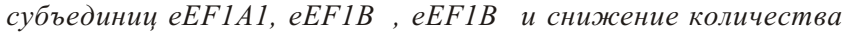
мРНК еЕFІВВ в глиобластомах по сравнению с условной нормой приблизительно в два раза. Также показано снижение уровня экспрессии мРНК еЕF1A2 в опухолевых образиах по сравнению с условно нормальной глией человека.

Ключевые слова: еEF1, эукариотный фактор элонгации трансляции 1, сверхэкспрессия гена, глиальные опухоли головного мозга человека.

\section{REFERENCES}

1. Negrutskii B.S., El'skaya A.V. Eukaryotic translation elongation factor 1a: structure, expression, functions, and possible role in aminoacyl-tRNA channeling // Progr. Nucl. Acids Res. Mol.Biol. - 1998. - 60. - P. 48 - 77.

2. Amons, R., Guerrucci, M.A., Karssies, R.H., Morales, J., Cormier, P., Muller, W. and Bellŭ, R. The leucine-zipper in elongation factor $E F-1_{A}$, a guanine-nucleotide exchange protein, is conserved in Artemia and Xenopus. // Biochim.Biophys. Acta. - 1994. - 1218. - P. 346-350.

3. Janssen, G.M.C., and Muller, W. Kinetic studies on the role of elongation factors 1 в and $1 \mathrm{r}$ in protein synthesis. // J. Biol. Chem. - 1988. - 263. - P. 1773 - 1778.

4. Janssen, G.M., van Damme, H.T.K., Kriek, J., Amons, R. and Muller, $W$. The subunit structure of elongation factor 1 from Artemia. // J. Biol. Chem. - 1994. - 269. - P. 31410 - 31417.

5. Tatsuka M., Mitsui H., Wada M., Nagata A., Nojima H., Okayama $H$. Elongation factor-1 alpha gene determines susceptibility to transformation.

Nature. - 1992. - 359. - P. 333-336.

6. Nisha Anand, Sabita Murthy, Gudrun Amann, Meredith Wernick, Lisa A. Porter, I. Howard Cukier, Colin Collins, Joe W. Gray, Joachim Diebold, Doug J. Demetrick \& Jonathan $M$. Lee. Protein elongation factor EEF1A2 is a putative oncogene in ovarian cancer. // Nat. Genet. - 2002. - 31. - P. 301-305.

7. Victoria A.L. Tomlinson, Helen J. Newbery, Naomi R. Wray, Juliette Jackson, Alexey Larionov, William R. Miller, J. Michael Dixon and Catherine M. Abbot. Translation elongation factor eEF1A2 is potential oncoprotein that is overexpressed in two-thirds of breast tumors. // BMC Cancer. - 2005. - 5. - P. 113 -120.

8. Chi K., Jones D.V., Frazier M.L. Expression of an elongation factor 1 gamma-related sequence in adenocarcinomas of the colon. // Gastroenterology. - 1992. - 103. - P. 98-102.

9. Lew Y., Jones D.V., Mars W.M., Evans D., Byrd D., Frazier M.L. Expression of elongation factor-1 gamma-related sequence in human pancreatic cancer. // Pancreas. - 1992. 7. - P. $144-152$.

10. Ender B., Lynch P., Kim Y.H., Inamdar N.Y., Cleary K.R., Frazier M.L. Overexpression of an elongation factor-1 
gamma-hybridizing RNA in colorectal adenomas. // Mol. Carcinogen. - 1993. - 7. - P. 18-20.

11. K. Ogawa, T. Utsunomiya, K. Mimori, Y. Tanaka, H. Inoue, S. Murayama and M. Mori. Clinical significance of elongation factor-1 delta mRNA expression in oesophageal carcinoma. // Br. J. Cancer. - 2004. - 91. - P. 282 - 286.

12. Massimiliano De Bortoli, Robert C Castelino, Xin-Yan Lu, Jeffery Deyo, Lisa Marie Sturla, Adekunle M Adesina, Lalslo Perlaky, Scott L Pomeroy, Ching C Lau, Tsz-Kwong Man, Pulivarthi H. Rao, John YH Kim. Medulloblastoma outcome is adversely associated with overexpression of EEF1D, RPL30, and RPS20 on the long arm of chromosome 8. // BMC Cancer. - 2006. - 6. - P. 223.

13. P. Chomczynski, N. Sacchi. Single-step method of RNA isolation by acid guanidinium thiocyonate-phenol-chloroform extraction. // Anal. Biochem. - 1987. - 162 - P. 156-159.
14. Sambrook, J., Fritsch, E.F., and Maniatis, T., in Molecular Cloning: A Laboratory Manual. Cold Spring Harbor Laboratory Press, NY, Vol. 1, 2, 3 (1989).

15. Pius Joseph, Christina M. O'Kernick, Sreekumar Othumpangat, Yi-Xiong Lei, Bao-Zhu Yuan, and Tong-Man Ong. Expression profile of eukaryotic translation factors in human cancer tissues and cell lines. // Mol. Carcinogen. 2004. - 40. - P. 171 - 179.

16. Daniel B. McClatchy, Charlotte R. Knudsen, Brian F. Clark, Richard A. Kahu, Randy A. Hall, and Allan I. Levey. Novel interaction the $\mathrm{M}_{4}$ muscarinic acetylcholine receptor and elongation factor $1 \mathrm{~A} 2$. // J. Biol. Chem. - 2002. - vol.277. No. 32. - P. 29268 - 29274.
UDC 577.217:577.112.7 Received 20.08.07 